\title{
CAPTIVE BREEDING OF MUD CRAB SCYLLA SERRATA (FORSKÅL, 1975) IN BANGLADESH
}

Md. Enamul Hoq*, Aung Sein ${ }^{1}$, Md. Shahzad Kuli Khan, Partho Pratim Debnath $^{1}$ and Quazi A.Z.M. Kudrat-E-Kabir ${ }^{1}$

\section{Marine Fisheries \& Technology Station, BFRI, Cox's Bazar, Bangladesh}

Crab is now only second to shrimp in terms of earnings in country's shellfish products export line-up. Crab farmers now depend completely on wild seed, which limits the expansion of crab culture in Bangladesh. The continuous collection of wild seeds for culture / fattening has threatened the wild population stock. Seed production of commercial important crab species has the potential to be an effective tool to support the demand of crab due depleted seed stock from the wild.

Fully gravid mud crabs, Scylla serrata (230 to $360 \mathrm{~g}$ body weight; 7.5 to $10.25 \mathrm{~cm}$ carapace length) were bought from tidal floodplain of Mosehkhali, Cox's Bazar and transported to the Niribili Hatchery, Krjukhal, Ukhia, Cox's Bazar. Prior to stocking in the hatchery, the crabs were bathed in a $100 \mu \mathrm{l} / 1$ formalin solution for an hour. The crabs were housed in cemented cistern, equipped with treated sea water supply. They were held in 10 tonnes cemented tanks provided with sand as substrate and PVC pipe for shelter. Rearing water was supplied from nearby sea water canal with tidal flow and pass through a complete water filtration system (sea water $>$ siltation tank $>$ quartz filter $>$ sand filter $>$ mollusk shell filter $>$ treatment tank $>$ curtis filter $>$ UV filter $>$ storage tank etc.) with central aeration system. The water tanks were chlorinated before use. Water temperature in the rearing tank was between $28.5^{\circ}-30^{\circ} \mathrm{C}$, salinity between 28-30 ppt, pH 7.8-8.1 and alkalinity was $153 \mathrm{mg} / \mathrm{L}$. Stocked crabs were fed fresh marine squid or flat fish alternately twice daily at $3 \%$ body weight. Excess feeds were siphoned out prior to feeding.

After 10-15 days of acclimation, unilateral eyestalk ablation of berried crab was applied to induce spawning. After eyestalk ablation, ablated crabs were again bathed in a $100 \mu \mathrm{l} / 1$ formalin solution for one hour and transferred to 300-L fibre glass tank for individual crab with aeration. Daily management consisted of siphoning out waste material from the tank bottom and controlling of temperature $\left(30^{\circ} \mathrm{C}\right)$, salinity $(30 \mathrm{ppt})$ and ammonia and nitrite levels. One to two days prior to hatching, the gravid mud crabs were moved to the laboratory of Marine Fisheries \& Technology Station, Cox's Bazar and kept in 300-L fibre glass tanks with central aeration system. The laboratory was maintained proper bio-security with aeration system, enough lightening and pretreated sea water

*Author for correspondence. E-mail: hoq_me@yahoo.com; 1Aquaculture for Income and Nutrition (AIN) Project, World Fish, Bangladesh. 
supply facilities. After 30-32 days of eyestalk ablation, egg formation was started and the crabs finally spawned after 45-47 days of eyestalk ablation.

The hatching process was completed within two days in fibre glass tanks. Aeration in the hatching tank was therefore turned off for several minutes and the larvae (zoea-I) that were actively swimming up to the surface were collected by gently scooping them from the surface. Over $85 \%$ of wild caught crabs brought into the laboratory or hatchery normally spawn, mostly within 40 days of stocking (Davis 2003, Mann et al. 1999). The zoea-I larvae were then transferred to the circular rearing tanks (300-L fibre glass tank). In order to slowly acclimate the larvae to the new rearing conditions, they were first placed in a 50-L plastic bucket and slowly rinsed with water from the larval rearing tanks for 20 to 30 minutes, before releasing them. For estimation of hatching rate, immediate after hatching, the zoea were taken in a $500 \mathrm{ml}$ beaker. Then, one-fourth milliliter $(0.25 \mathrm{ml})$ samples were counted and calculate the total zoea numbers followed the estimation of hatching rate. During present experimental trial, four gravid crabs hatched from 15 December and onwards and produced 3.2, 1.6, 2.6 and 1.9 million zoea-I, respectively.

For feeding of newly hatched zoea, micro-algae Nannochloropsis $s p$. were cultured in seawater of $30 \mathrm{ppt}$ at $25^{\circ} \mathrm{C}$ using Guillard's F/2 media. Large-scale indoor production was performed in 500-L tanks with continuous aeration and sufficient florescent light. A hemocytometer was used to count micro-algal densities. Besides, rotifers were cultured indoor in 100-L white plastic tanks operated in batch mode, following the procedure described in Sorgeloos and Lavens (1996). Rotifers were initially grown on baker yeast, but one week before use as feed for the larvae, the yeast was replaced by Culture Selco ${ }^{\circledR}$ (INVE Aquaculture, Belgium). Temperature was controlled using thermostat heaters in the culture tanks at $25^{\circ} \mathrm{C}$ and salinity at $30 \mathrm{ppt}$. They were harvested through a $60 \mu \mathrm{m}$ screen and rinsed thoroughly. Rotifers were enriched with micro-algae before being fed to the crab larvae. Enrichment was performed at a density of 500 rotifers $\mathrm{ml} / \mathrm{L}$. The water in the enrichment vessel was slowly heated to 28 $30^{\circ} \mathrm{C}$ to avoid exposing the rotifers to thermal shock when they were added to the larval rearing tanks. Artemia nauplii (Pro-80, USA) were hatched as described by Van Stappen (1996). Artemia were enriched with Chaetoceros in the same micro-algal density as for rotifer enrichment. The temperature and salinity were maintained at $30^{\circ} \mathrm{C}$ and $30 \mathrm{ppt}$, respectively during Artemia enrichment. The density of Artemia during enrichment was $200 \mathrm{ml} / \mathrm{L}$. Before feeding to the crab larvae, the Artemia were rinsed with disinfected seawater and suspended at a known density in seawater. 
Larval survival and growth of newly hatched zoea-I was compared with three treatments using OTC-90 (OTC 90\%+Sucrose 10\%), ciprofloxacin and a probiotic (Vib-con 10, USA) in pretreated sea water with alternate day partial water exchange. Live feed and crab larvae were retained in the rearing tanks with the help of a mesh screen of 70 and $300 \mu \mathrm{m}$ during the rotifer and Artemia feeding stage, respectively. Daily siphoning was done in each treatment to flushing out uneaten live feed, dead larvae and waste. During rearing, heavy protozoan infestation was observed in larvae of treatments with ciprofloxacin and probiotics, but not in the treatment with OTC. The probable source of protozoan infection was identified as supplied live feeds. To overcome the problem protozoacide (Proto-D) was applied in live feed culture media. The application of Proto-D reduced the protozoan attack. Laboratory cultures of crab larvae often suffer severe mortality from disease, particularly from epibiotic bacteria and larval mycosis (Armstrong et al. 1976, Hamasaki and Hatai 1993). In larval rearing of S. serrata up to $80 \%$ of the mortality could be attributed to bacteriological causes and oxytetracycline proved the best prophylactic chemical for crab larvae (Nghia 2005). Pathogenic bacteria are considered as one of the most serious causes for the high mortality of early crab larvae. It can be safely assumed that all inputs (seawater, live feed and daily management in rearing) into the culture tank are potential sources of infection (Blackshaw 2001). Unfortunately, in the present trial, first 3 zoea batches from 3 hatched crabs were survived up to zoea-IV stage, after mass mortality due to contamination in larval rearing tanks. The representative portion of 1.9 million zoea from the last hatched crab was carefully reared in the laboratory with the above 3 treatments for a period of 15 days and representative numbers of megalopa were produced from OTC treatment. Moreover, sudden mass mortality of megalopa was observed due to luminous bacterial infection, which was overcome with antibiotic (Furacin) treatment. The overall survival from zoea to megalopa stage was about $1.3 \%$, although rearing of 1.9 million zoea was not possible due to limitation of rearing facilities in the laboratory. Studies of rearing of mud crab larvae from Indonesia (Marjono and Arifin 1993), Vietnam (Hoang 1999), Philippine (Quinitio 2001) and India (RGCA 2014) showed the survival rate of $3.2 \%, 3.7 \%, 24 \%$ and $8 \%$, respectively. In the present study, finally crablets were produced from the megalopa after 10 days or rearing- a total of 25-27 days required to produced crablet in controlled condition. Mud crab has a complex life cycle, where the larvae go through five zoea stages (3-5 days each) and one megalopa stage (8-10 days) before finally metamorphosing into the benthic first juvenile crab stage (crablet, Fig. 1). This is the first time in Bangladesh to produce crablet from artificial propagation of mud crab. In an attempt Sarowar et al. (2012) reported only hatching of mud crab in captive condition in 
Bangladesh. Once the megalopa was obtained they were carefully separated and transferred to 100-L plastic tank and small PVC pipe cuttings were placed all over the tank bottom for attachment and refuge. The crablets were fed with minced fresh marine squid.

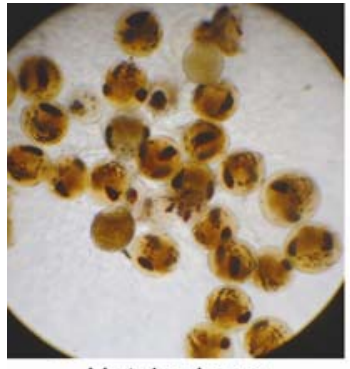

Hatched egg

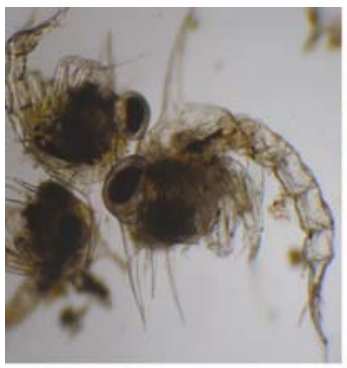

Zoea-IV

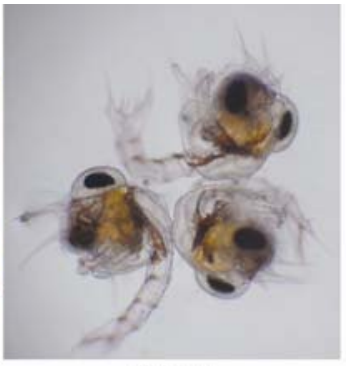

Zoea-I

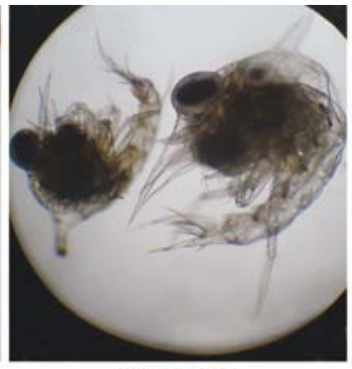

Zoea-V

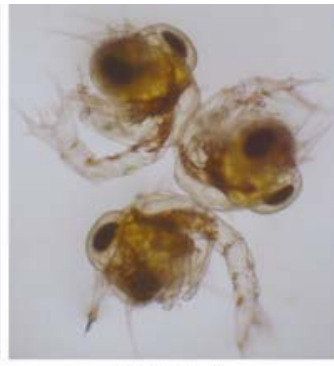

Zoea-II

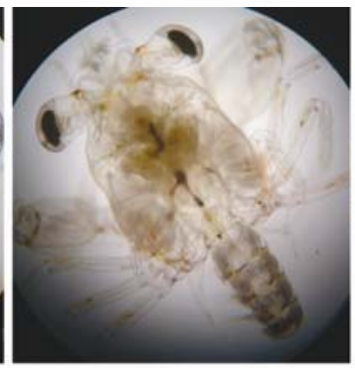

Megalopa

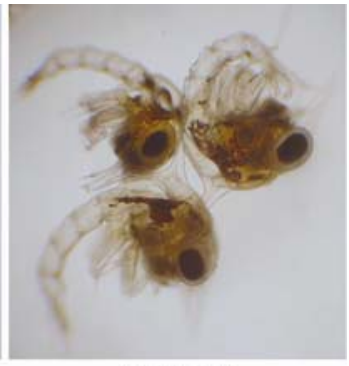

Zoea-III

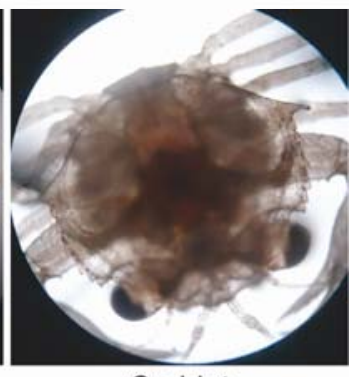

Crablet

Fig. 1. Hatched eggs to crablet stages under the captive breeding of mud crab.

The most important requirement for mud crab breeding is clean seawater. It is therefore essential to provide facility for water treatment in the hatchery depending on the quality of source water. Aside from improving live feed quality to meet all nutritional requirements of the larvae, the biggest challenge for crab larval rearing will probably be the development of safe and sustainable prophylactic treatments to prevent microbial interactions. Although several issues still need to be solved, it may conclude that knowledge of mud crab breeding and larval rearing techniques have, in recent years, evolved to a level comparable to that of shrimp in the early nineties, and therefore commercial application might be envisaged within a few year time in the country.

Acknowledgement: The authors wishes to acknowledge Aquaculture for Income and Nutrition (AIN) Project under USAID, WorldFish, Bangladesh and Marine Fisheries \& Technology Station, BFRI for providing technical and financial support. 


\section{LITERATURE CITED}

ARMSTRONG, D.A., BUCHANAN, D.V. and CALDWELL, R.S. 1976. A mycosis caused by Lagenidium spp. in laboratory reared larvae of the Dungeness crab, Cancer magister and possible chemical treatments. J. Invertebrate Pathology, 28: 329-336.

BLACKSHAW, A.W. 2001. Larval culture of Scylla serrata: maintenance of hygiene and concepts of experimental design. Asian Fisheries Sci. 14(2): 239-242.

DAVIS, J.A. 2003. Development of hatchery techniques for the mud crab Scylla serrata (Forskal) in South Afica. PhD Thesis. Faculty of Agricultural and Applied Biological Sciences, Ghent University, Belgium, $163 \mathrm{p}$.

HAMASAKI, K. and HATAI, K. 1993. Prevention of fungal infection in the eggs and larvae of the swimming crab Portunus trituberculatus and the mud crab Scylla serrata by bath treatment with formalin. Bull. Japanese Soc. Sci. Fish., 59(6): 1067-1072.

HOANG DUC DAT, 1999. Preliminary studies on rearing the larvae of the mud crab (Scylla paramamosain) in south Vietnam. pp 147-152. Keenan, C.P. and Blackshaw, A. (eds.). Mud Crab Aquaculture and Biology. Proceedings of an international scientific forum held in Darwin, Australia, 21-24 April 1997. ACIAR Proc. 78: 216 p.

HOQ, M.E. and RAHMAN, S.L. 1995. Some observation on the mud crab (Scylla serrata) and its fishery at Paikgacha, Bangladesh. Bangladesh J. Fish. 15-18(1-2): 83-90.

MANN, D., ASAKAWA, T. and BLACKSHAW, A. 1999. Performance of mud crab Scylla serrata brood stock held at Bribie Island Aquaculture Research Center. In: Keenan, C.P. and Blackshaw, A. (eds.). Mud Crab Aquaculture and Biology. Proc. of an international scientific forum held in Darwin, Australia, 21-24 April 1997. ACIAR Proc. 78: 101-105.

MARDJONO, M. and ARIFIN, M. 1993. Pemeliharaan larva kepiting dengan tingkat kepadatan yang berbeda (rearing experiments of the mud crab using different stocking densities). Laporan Tahunan Bbap Jepara (Annual Report of the Brackishwater Aquaculture Development Center of DGF, Jepara).

NGHIA, T.T. 2005. Optimization of mud crab (Scylla paramamosain) larviculture in Vietnam. PhD Thesis, Gent University, Belgium. 192 p.

QUINITIO, E.T., PARADO-ESTEPA, F.D., MILlAMENA, O.M., RODRIGUEZ, E. and BORLONGAN, E. 2001. Seed production of mud crab Scylla serrata juveniles. Asian Fish. Sci. 14: 161-174

RGCA 2014. Report on Mud Crab Hatchery Project. Rajiv Gandhi Centre for Aquaculture.

SAROWER, M.G., AKTAR, N., MOSTAFA, M., SABBIR, W. and ISLAM, M.S. 2012. Some aspects of captive breeding biology of mud crab, Scylla serrata in Bangladesh. J. Innov. Dev. Strategy 6(2): $1-6$

SORGELOOS, P. and LAVENS, P. 1996. Manual on the production and use of live food for aquaculture. Fisheries Technical Paper 361. Food and Agriculture Organization of the United Nation, Rome, $100 \mathrm{p}$.

VAN STAPPEN, G. 1996. Artemia. In: Lavens, P.,Sorgeloos, P. (eds.). Manual on the production and use of live food for aquaculture. FAO Technical Paper 361. Food and Agricultural Organization, Rome, pp. 101-170. 